\title{
The Relationship between Parents' Socio-Economic Background and Students' Science Literacy in Indonesia: Evidence from Programme for International Students Assessment (PISA) 2015
}

\author{
Mariana \\ Universitas Negeri Surabaya \\ Surabaya, Indonesia \\ mariana@unesa.ac.id
}

\begin{abstract}
Progress of a nation is determined by the ability of its human resources in mastering science and technology. Science literacy has an important role for students to prepare the quality of Indonesian human resources in the future. The objective of the study was to identify the socio-economic variables that predicted the students' science literacy in Indonesia in reference to PISA 2015. The data were taken from PISA 2015 involving those in fifteen-year old. The samples of the study consisted of 6,513 students spread throughout Indonesia. Regression analysis showed that parents' providing learning facilities to children have the most significant relationship to science literacy results, while the amount of wealth, occupation, and level of parental education are not related to children's science literacy. The research concluded that parents as educators have an important role in the future of children, one of them through giving learning facilities such as providing learning tools, supporting books, computers at home.
\end{abstract}

Keywords - family background, science achievement, middle school, international survey

\section{INTRODUCTION}

Progress of a nation is determined by the ability of its human resources in mastering science and technology. Science literacy has an important role for students to prepare the quality of Indonesian human resources in the future. In science literacy students are accustomed to analyze, think logically, think critically, creatively, and be able to problem solver that is around it. These skills are important for the future of Indonesian students. Habit of mind is the result of long-term learning. According to Rustaman thinking habits can be divided into critical thinking, creative thinking and selfregulation. The third slice of thinking habits also determine the level of confidence and personality.

PISA survey results in 2015 followed by 72 countries shows the achievement of education in Indonesia increased by 22.1 points. The increase in Indonesia's performance in 2015 is quite optimistic, although still low compared to the OECD average. Based on the average score, an increase in the value of PISA Indonesia in the three competences tested. The largest increase seen in science competence, from 382 points in 2012 to 403 points in 2015. In the mathematical competence increased from 375 points in 2012 to 386 points in 2015 . Reading competencies have not shown significant increase, from 396 in 2012 to 397 points in 2015. The increase raised the position of Indonesia 6 ranks upward compared to the second rank position from below in 2012. The number of samples participating in the 2015 PISA survey continued to increase, by 46 percent in 2003 to 53 percent in in 2006 and 2009. Furthermore, the figure rose to 63.4 percent in 2012, and to 68.2 percent in 2015 [1].

Research conducted by Rogers Pakpahan [2] referring to PISA 2012 found that the inherent social conditions in parents are significantly related to student achievement. Working parents are expected to provide the means of books, computers, and other means to support student learning activities. The condition of ownership of learning facilities, books, and computers also shows that there is a significant relationship between ownership of learning achievement.

The results of Patrícia et al. [3] The Reading Literacy Achievement in EU Countries shows that the availability of home resources is a key factor in reading performance. Research Students' achievement of Malaysian 21st century skills in chemistry conducted by Nur Suhaidah et al. [4] using data from TIMSS 2007. In the study revealed that students from high socioeconomic status managed to score higher yields than their counterparts from low socioeconomic status.

According to Grissmer [5], parents' level of education is the most important factor affecting students' academic achievement. Taiwo [6] submits that parents' educational background influence the academic achievement of students. This, according to him, is because the parents would be in a good position to be second teachers to the child; and even guide and counsel the child on the best way to perform well in education and provide the necessary materials needed by him/her. This was supported by Musgrave [7] who said that a child that comes from an educated home would like to follow the steps of his/her family and by this, work actively in his/her studies. 
This research is trying to find the relationship between science literacy with family socio-economic background. Families in this case are parents. Parents have a big role in children's education. Children is a mandate for parents, to educate and develop into a person who morals start, independent and knowledgeable. Educational responsibility is a shared responsibility between parents, schools, the environment and government. Family education is a major education for the future of children, because children first learn from the family environment. Families or parents who pay attention to the education of their children will have an impact on the child's learning achievement. The economic condition of a good family can provide education and learning facilities for children, both at home and at school. Highly educated parents also affect student achievement. Based on the above research the socio-economic factors of the family have a significant influence on student achievement through science literacy. PISA 2015 findings are in line with the results of analysis conducted Anindito Aditomo and Ide Bagus Siaputra [8], researchers from the University of Surabaya, against the results of national examinations (UN) high school students and vocational schools in 2016 that confirm the link between student achievement and socioeconomic status of students represented by the level of parental education and the type of parent work.

The objective of the study was to identify the socioeconomic variables that predicted the student science literacy in Indonesia in reference to PISA 2015. The PISA study is a study to determine important knowledge of citizens and skills that can be undertaken [9]. PISA aims to measure the extent to which basic education in a country is able to prepare students (citizens) to face the real world, to reach higher knowledge, to socialize in the global arena, and to meet basic needs.

\section{RESEARCH METHODS}

This research is a quantitative research with PISA survey taken in 2015 followed by 72 countries including Indonesia. This study sampled Indonesian students by the age of 15 years. The sample of the study consisted of 6,513 students spread all over Indonesia. In Indonesia the age of 15 years averaged sitting in the 9th and 10th grade. Class 9 is the same as the $3 \mathrm{rd}$ grade junior high school, while the 10th grade is the same as the 1st grade senior high school. The analysis used in this study used multiple regression method with 7 predictors, namely Family wealth, Cultural possessions at home, ISEI of mother, ISEI of father, Home educational resources, Index highest parental occupational status, Home possessions. From 7 predictors there were 4 significant predictors and 3 insignificant predictors. Significant predictors consist of Cultural possessions at home, ISEI of father, Home educational resources, Home possessions. While 3 insignificant predictors are Family wealth, Index highest parental occupational status, and ISEI of mother. From some indicators Home educational resources is a variable that is very influential on children's science literacy.

Variable used in this research:
TABLE I. VARIABLE AND OPERATIONAL DEFINITION

\begin{tabular}{|c|c|}
\hline Variable Name & Operational definition \\
\hline ISEI of mother & $\begin{array}{l}\text { The International Student Social Assessment } \\
\text { Index (ISEI) International Students Assessment } \\
\text { (PISA) is the student's response to the work of the } \\
\text { parent (mother). }\end{array}$ \\
\hline ISEI of father & $\begin{array}{l}\text { The International Student Social Assessment } \\
\text { Index (ISEI) International Students Assessment } \\
\text { (PISA) is the student's response to the work of } \\
\text { parents (father). }\end{array}$ \\
\hline $\begin{array}{l}\text { Index highest parental } \\
\text { occupational status }\end{array}$ & $\begin{array}{l}\text { The Index was derived from the International } \\
\text { Standard Classification of Occupations (ISCO), } \\
\text { using comparably coded data on education, } \\
\text { occupation, and income for } 73,901 \text { full-time } \\
\text { employed men from } 16 \text { countries }\end{array}$ \\
\hline $\begin{array}{l}\text { Cultural possessions at } \\
\text { home }\end{array}$ & $\begin{array}{l}\text { The index of cultural possessions (CULTPOSS) is } \\
\text { based on students' responses to whether they had } \\
\text { the following at home: classic literature, books of } \\
\text { poetry and works of art (some items in ST26). }\end{array}$ \\
\hline $\begin{array}{l}\text { Home educational } \\
\text { resources }\end{array}$ & $\begin{array}{l}\text { The index of home educational resources } \\
\text { (HEDRES) is based on the items measuring the } \\
\text { existence of educational resources at home } \\
\text { including a desk and a quiet place to study, a } \\
\text { computer that students can use for schoolwork, } \\
\text { educational software, books to help with students' } \\
\text { school work, technical reference books and a } \\
\text { dictionary (some items in ST26). }\end{array}$ \\
\hline Home possessions & The index of ESCS including books in the home \\
\hline Family wealth & $\begin{array}{l}\text { The index of family wealth (WEALTH) is based } \\
\text { on students' responses on whether they had the } \\
\text { following at home: a room of their own, a link to } \\
\text { the Internet, a dishwasher (treated as a country- } \\
\text { specific item), a DVD player, and three other } \\
\text { country-specific items (some items in ST26); and } \\
\text { their responses on the number of cellular phones, } \\
\text { televisions, computers, cars and the number of } \\
\text { rooms with a bath or shower (ST27). }\end{array}$ \\
\hline
\end{tabular}

\section{RESULTS AND DISCUSSION}

Regression results are shown in the table below:

TABLE II. MODEL SUMMARY

\begin{tabular}{|l|c|l|l|l|}
\hline Model & $\boldsymbol{R}$ & $\boldsymbol{R}$ Square & Adjusted $\boldsymbol{R}$ Square & Std. Error of the Estimate \\
\hline 1 & $.427^{\mathrm{a}}$ & .182 & 180 & 63.557469 \\
\hline
\end{tabular}

a. Predictors: (Constant), Family wealth, Cultural possessions at home, ISEI of mother, ISEI of father, Home educational resources, Index highest parental occupational status, Home possessions.

TABLE III. ANOVA

\begin{tabular}{|c|c|c|c|c|c|c|}
\hline \multicolumn{2}{|c|}{ Model } & Sum of Squares & Df & $\begin{array}{c}\text { Mean } \\
\text { Square }\end{array}$ & F & Sig. \\
\hline \multirow{3}{*}{1} & Regression & 2547367.770 & 7 & 363909.681 & 90.087 & $.000^{b}$ \\
\cline { 2 - 8 } & Residual & 11448090.167 & 2834 & 4039.552 & & \\
\cline { 2 - 8 } & Total & 13995457.938 & 2841 & & & \\
\hline
\end{tabular}

\section{a. Dependent Variable: Plausible Value 1 in Science}

b. Predictors: (Constant), Family wealth, Cultural possessions at home, ISEI of mother, ISEI of father, Home educational resources, Index highest parental occupational status, Home possessions. 
This research model is sufficient to predict the science literacy shown by the probability of $\mathrm{F}$ significant at the $1 \%$ level. Independent variable socioeconomic condition of parents consisting of 7 indicators (Family wealth, Cultural possessions at home, ISEI of mother, ISEI of father, Home educational resources, Index highest parental occupational status, Home possessions) can predict the $18 \%$ science literacy shown from the Adjusted R Square value.

TABLE IV. COEFFICIENTSA

\begin{tabular}{|c|c|c|c|c|c|}
\hline Model & $\begin{array}{r}\text { Unst: } \\
\text { Co }\end{array}$ & $\begin{array}{l}\text { lardized } \\
\text { cients }\end{array}$ & \begin{tabular}{|c|} 
Standardized \\
Coefficients
\end{tabular} & $\mathbf{T}$ & Sig. \\
\hline & $B$ & Std. Error & Beta & & \\
\hline (Constant) & 440.922 & 4.939 & & 89.278 & .000 \\
\hline \begin{tabular}{|ll} 
ISEI & of \\
mother
\end{tabular} & .230 & .141 & .067 & 1.633 & .103 \\
\hline \begin{tabular}{|ll}
$\begin{array}{l}\text { ISEI } \\
\text { father }\end{array}$ & of \\
\end{tabular} & .236 & 120 & .067 & 1.965 & .049 \\
\hline \begin{tabular}{|l|} 
Index \\
highest \\
parental \\
occupational \\
status \\
\end{tabular} & .031 & .179 & .010 & .172 & .863 \\
\hline $\begin{array}{l}\text { Cultural } \\
\text { possessions } \\
\text { at home }\end{array}$ & -5.598 & 2.185 & -.059 & -2.562 & .010 \\
\hline $\begin{array}{l}\text { Home } \\
\text { educational } \\
\text { resources }\end{array}$ & 11.145 & 2.338 & .172 & 4.768 & .000 \\
\hline \begin{tabular}{|l|} 
Home \\
possessions
\end{tabular} & 8.928 & 4.783 & .166 & 1.867 & .062 \\
\hline $\begin{array}{l}\text { Family } \\
\text { wealth }\end{array}$ & 2.189 & 3.281 & .043 & .667 & .505 \\
\hline
\end{tabular}

\section{a. Dependent Variable: Plausible Value 1 in Science}

The result of statistical test using regression shows that from 7 socio-economic indicators of parents proves 4 significant indicators have influence on science literature. The four indicators are Cultural possessions at home, ISEI of father, Home educational resources, Home possessions. ISEI of father is significant at $5 \%$ level, Cultural possessions at home at level 1 , Home educational resources at level $1 \%$ (highest), Home possessions at level $10 \%$.

The Program for International Student Assessment (PISA) index of economic, social and cultural status was created on the basis of the following variables: the International SocioEconomic Index of Occupational Status (ISEI); the highest level of education of the student's parents, converted into years of schooling; the PISA index of family wealth; the PISA index of home educational resources; and the PISA index of possessions related to "classical" culture in the family home.

On average across OECD countries, parents of socioeconomically advantaged students are highly educated: a large majority has attained tertiary education $(97 \%)$ and works in a skilled, white-collar occupation (94\%). By contrast, the parents of socio-economically disadvantaged students have much lower educational attainment. Across OECD countries, $55 \%$ of parents of disadvantaged students attained some postsecondary non-tertiary education as their highest level of formal schooling, 33\% attained lower secondary education or less, and only $12 \%$ attained tertiary education. Few disadvantaged students have a parent working in a skilled occupation (8\%); many parents of these students work in semiskilled, white-collar occupations (43\%), and the majority $(49 \%)$ work in elementary occupations or semi-skilled, bluecollar occupations.

One of the home possessions that most clearly distinguishes students of different socio-economic profiles is the quantity of books at home. While $47 \%$ of advantaged students reported having more than 200 books at home, on average, this is the case for only $7 \%$ of disadvantaged peers. Advantaged students also reported a greater availability of other educational resources, such as educational software. On average across OECD countries, however, more than $80 \%$ of students, regardless of their socio-economic status, reported having a quiet place to study at home.

At the individual level, analyses in this chapter consider the relationship between each student's socio-economic status and his or her science performance and attitudes towards science as assessed in PISA 2015 [10], with an occasional focus on other domains as well. At the school level, the analyses consider the relationship between the average socio--economic status of 15year-old students in the school and the scores of the 15-yearolds attending that school. At the country level, the socioeconomic status of students, both on average and its distribution within the country, can be related to average performance at the school-system level.

The 2015 PISA report entitled "Excellence and Equity in Education" which was released on December 6, 2016 shows that excellence and equity can be championed simultaneously as exemplified by Denmark, Canada, Estonia, Hong Kong and Macao [9]. The 2015 PISA results do represent a marked improvement in the achievement of Indonesian students of 15 years in science and mathematics compared to 2012. The average score of Indonesian students in PISA 2015 for science, reading and math is 403,397 , and 386 , respectively. The average scores for science, reading, and mathematics in 2012 are 382,396 , and 375 respectively. Nevertheless, the average score is still below the ASEAN countries participating in PISA, namely Singapore, Vietnam, and Thailand, and still in the lowest group.

Although the achievement of Indonesian students in science and mathematics based on the results of PISA 2015 shows an increase compared to PISA 2012, it turns out that socioeconomic factors still become one of the inhibitors of students to reach their maximum potential, even tends to strengthen. For example, for science, the average scores of students from the lowest to the highest quintile of socioeconomic status were $378,393,403$, and 438, respectively. The difference between the mean scores between students of the lowest and highest socioeconomic groups reached 60 points. Although there are exceptions, in general, the average scores of students from more affluent families tend to be higher than the average scores of students from disadvantaged families. The students who did not reach Level 2 based on the lowest socioeconomic status until the highest was $71.1 \%, 61.9 \%, 54.4 \%$ and $36.2 \%$, respectively. The percentage of students from the lowest socioeconomic status group who did not reach Level 2 doubled 
compared with the students of the highest socioeconomic status group. Level 2 is seen as a basic ability in applying the knowledge and skills possessed by 15 -year-old students in science, reading, or math to solve daily problems. Thus, the lower the socioeconomic status, the higher the chances of students not reaching these basic skills levels.

The data of the students who sampled in the study consisted of 6,513 students aged 15 years in Indonesia showed that the variable that is very influential in increasing the literacy of science is home educational resources. This suggests that good socioeconomic conditions in the parents should be allocated in the fulfillment of learning needs in children such as the availability of reading books, computers or other learning support tools.

Home educational resources is an indicator that contributes the most in improving science literacy. The science literacy which is also an indicator of learning achievement is greatly influenced by the availability of learning and education facilities at home. Rich parents do not guarantee their children achievement if the wealth is not used to improve home study facilities. Provision of home study facilities is shown how many books are available. The more reading books with variations of the types and forms that parents provide will improve student learning achievement. The use of computers at home also helps students in improving learning achievement.

Cultural possessions at home in the form of classic literature, books of poetry and works of art contribute to the achievement of student achievement. Parents' work, especially father, also contributes to the achievement of student achievement. This phenomenon shows the importance of the role of parents in the education of their children. Socioeconomic background of good parents is expected to improve the quality of education of children in the future. Education here in a broad sense, is not only able to have good grades or high GPA but what about good education, children have good character, able to solve problems well and always learn new things for progress and achievement.

\section{CONCLUSION}

The research concluded that parents as educators have an important role in the future of children, one of them through giving learning facilities such as providing learning tools, supporting books, computers at home. Provision of home study facilities and correct direction from parents will encourage students to excelent. Parents with high or rich socioeconomic conditions have a greater opportunity to provide learning facilities for children at home. So that parents have a big role in supporting student achievement. Wise parents will use their wealth for the education and achievements of their children.

\section{REFERENCE}

[1] “A." [Online]. Available: www.kemdikbud.go.id.

[2] R. Pakpahan, "Factors Affecting Literacy Mathematics Achievement," $J$. Pendidik. dan Kebud., vol. 1, no. 3, 2016.

[3] P. A. Almeida, P. Costa, and L. Araújo, "Read Me A Story: Reading Literacy Achievement in EU Countrie," Procedia - Soc. Behav. Sci., vol. 177, pp. 358-362, 2015.
[4] N. S. Sukor, K. Osman, and M. Abdullah, "Students' achievement of Malaysian 21st century skills in chemistry," Procedia Soc. Behav. Sci., vol. 9, pp. 1256-1260, 2010.

[5] R. H. Grissmer, "Beyond Helping with Homework: Parents and Children Doing Mathematics at Home," Teach. Child. Math., vol. 14, pp. 120-131, 2003.

[6] H. G. Taiwo, "Family Environment and Educational Attainment of Some School Children in Western Nigeria," J. Sci. Teach. Assoc. Niger., vol. 46, no. 2, pp. 107-116, 1993.

[7] C. B. Musgrave, "Environmental Factors Affecting Attitude towards Science and Mathematics," J. Educ. Psychol., vol. 91, no. 1, pp. 382 394, 2000.

[8] A. Aditomo and I. B. Siaputra, "Peran Lingkungan Rumah dalam Prestasi Belajar Siswa SMA dan SMK: Hasil Analisis Data Survei Peserta Ujian Nasional 2016," 2016.

[9] OECD, PISA 2015 Results (Volume I): Excellence and Equity in Education. Paris: OECD Publishing, 2016.

[10] OECD, PISA 2015 Results (Volume II): Policies and Practices for Successful Schools. Paris: OECD Publishing, 2016. 